\title{
ORIGINS OF SECONDARY SILICA WITHIN YUCCA MOUNTAIN, NYE COUNTY, SOUTHWESTERN NEVADA
}

\section{U.S. GEOLOGICAL SURVEY}

Open-File Report 95-289

Prepared in cooperation with the NEVADA OPERATIONS OFFICE, U.S. DEPARTMENT OF ENERGY, under Interagency Agreement DE-AI08-92NV10874

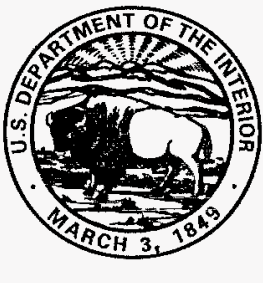




\section{ORIGINS OF SECONDARY SILICA WITHIN YUCCA MOUNTAIN, NYE COUNTY, SOUTHWESTERN NEVADA}

by Richard J. Moscati and Joseph F. Whelan

U.S. GEOLOGICAL SURVEY

$$
\text { USGS-OFP--95-289 }
$$

Open-File Report 95-289

Prepared in cooperation with the

NEVADA OPERATIONS OFFICE,

U.S. DEPARTMENT OF ENERGY, under

Interagency Agreement DE-Al08-92NV10874

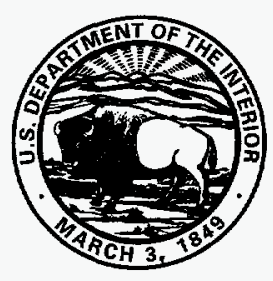




\title{
U.S. DEPARTMENT OF THE INTERIOR BRUCE BABBITT, Secretary
}

\author{
U.S. GEOLOGICAL SURVEY \\ Gordon P. Eaton, Director
}

\section{DISCLAIMER}

\begin{abstract}
This report was prepared as an account of work sponsored by an agency of the United States Government. Neither the United States Government nor any agency thereof, nor any of their employees, makes any warranty, express or implied, or assumes any legal liability or responsibility for the accuracy, completeness, or usefulness of any information, apparatus, product, or process disclosed, or represents that its use would not infringe privately owned rights. Reference herein to any specific commercial product, process, or service by trade name, trademark, manufacturer, or otherwise does not necessarily constitute or imply its endorsement, recommendation, or favoring by the United States Government or any agency thereof. The views and opinions of authors expressed herein do not necessarily state or reflect those of the United States Government or any agency thereof.
\end{abstract}

The use of trade, product, industry, or firm names is for descriptive purposes only and does not imply endorsement by the U.S. Government.

For additional information write to: Chief, Earth Science Investigations Program Yucca Mountain Project Branch U.S. Geological Survey

Box 25046, MS 421

Denver Federal Center

Denver, CO 80225
Copies of this report can be purchased from: U.S. Geological Survey Information Services

Box 25286

Denver Federal Center

Denver, CO 80225 


\section{DISCLAIMER}

Portions of this document may be illegible in electronic image products. Images are produced from the best available original document. 


\section{CONTENTS}

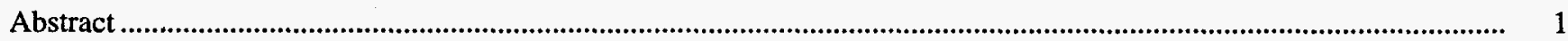

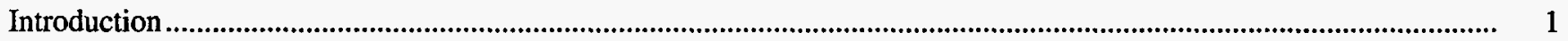

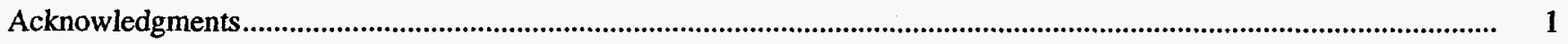

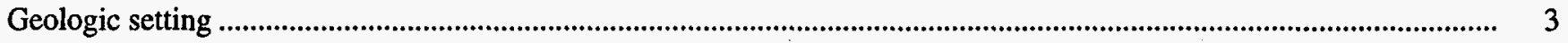

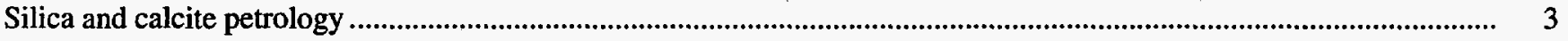

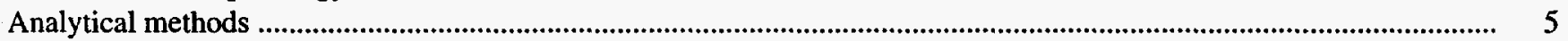

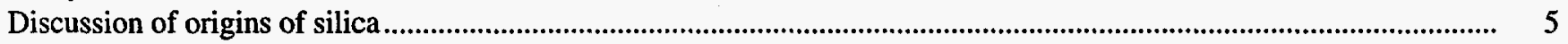

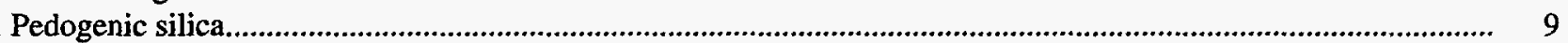

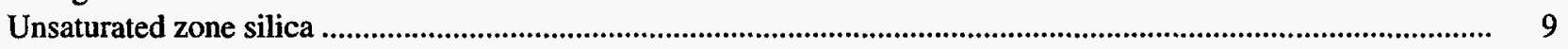

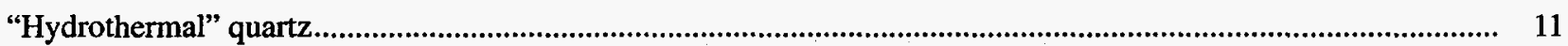

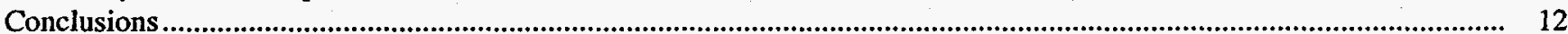

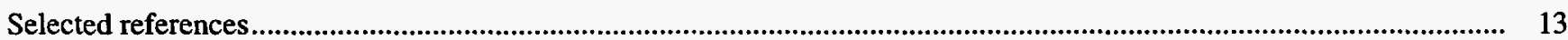

\section{FIGURES}

1. Maps showing location of Yucca Mountain region and potential repository site, sampled boreholes, Trench 14, and the Bullfrog Mine

2. Approximately north-south, generalized cross section of Yucca Mountain showing geology, water table, and boreholes.

3-7. Graphs showing:

3. Delta ${ }^{13} \mathrm{C}$ (crosses) and $\delta^{18} \mathrm{O}$ (circles) values of secondary calcite from all boreholes with respect to location of the water table

4. Variation in $1000 \ln \alpha$ (mineral-water) with temperature for ${ }^{18} \mathrm{O}$ in silica and calcite 8

5. Delta ${ }^{18} \mathrm{O}$ values of pedogenic and borehole secondary silica samples

6. Calculated temperatures, assuming $\delta^{18} \mathrm{O}$ water $=-12.5 \%$, of Trench 14 soil zone opals (diamonds), unsaturated zone opals (circles), and unsaturated zone calcite (crosses).....

7. Delta ${ }^{18} \mathrm{O}$ values of the relatively lighter Bullfrog Mine and saturated zone silica samples relative to those in Trench 14 and the unsaturated zone.

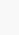

.




\begin{tabular}{|c|c|c|}
\hline Multiply & By & To obtain \\
\hline $\begin{array}{r}\text { meter }(\mathrm{m}) \\
\text { millimeter }(\mathrm{mm}) \\
\text { kilogram }(\mathrm{kg}) \\
\text { kilometer }(\mathrm{km})\end{array}$ & $\begin{array}{l}3.2808 \\
0.03937 \\
2.2046 \\
0.6214\end{array}$ & $\begin{array}{l}\text { foot } \\
\text { inch } \\
\text { pound } \\
\text { mile }\end{array}$ \\
\hline
\end{tabular}

Degree Celsius $\left({ }^{\circ} \mathrm{C}\right)$ may be converted to degree Fahrenheit $\left({ }^{\circ} \mathrm{F}\right)$ by using the following equation:

$$
{ }^{\circ} \mathrm{F}=9 / 5\left({ }^{\circ} \mathrm{C}\right)+32 \text {. }
$$

The following term is also used in this report:

Ma millions of years old

Sea level: In this report "sea level" refers to the National Geodetic Vertical Datum of 1929 (NGVD of 1929)—a geodetic datum derived from a general adjustment of the first-order level nets of both the United States and Canada, formerly called Sea Level Datum of 1929. 


\title{
Origins of Secondary Silica Within Yucca Mountain, Nye County, Southwestern Nevada
}

\author{
By Richard J. Moscati and Joseph F. Whelan
}

\section{Abstract}

The accuracy of predictions of the hydrologic response of Yucca Mountain to future climate depends largely on how well relations between past climate and hydrology can be resolved. To advance this reconstruction, secondary minerals in and near Yucca Mountain, deposited by ground waters that originated both as surficial recharge at Yucca Mountain and from regional aquifers, are being studied to determine past ground-water sources and chemistries.

Preliminary data on stable oxygen isotopes indicate that, although silica (opal, quartz, and chalcedony) and calcite and have formed in similar settings and from somewhat similar fluids, we have found no compelling evidence of coprecipitation or formation from identical fluids. If verified by further analyses, this precludes the use of silica-calcite mineral pairs for precise geothermometry. The preliminary data also indicate that opal and calcite occurrences in pedogenic and unsaturated-zone settings are invariably compatible with formation under modern ambient surface or subsurface temperatures. Pedogenic calcite and opal appear to require somewhat different fluid chemistries and these differences likely reflect different climate states. Opal may, therefore, provide an easily datable (Uranium/Thorium method) secondary phase in paleosols and in the unsaturated zone that records major climate transitions.

Silica and calcite stable-isotope studies are being integrated with soil geochemical modeling. This modeling will define the soil geochemical condition (climate) leading to opal or calcite deposition and to the transfer functions that may apply at the meteoric soil unsaturated-zone interfaces. Additional study of pedogenic and unsaturatedzone silica is needed to support these models.

The hypothesis that the transformation of vapor-phase tridymite to quartz requires saturated conditions is being tested through stable oxygenisotope studies of lithophysal tridymite/quartz mixtures. Should this hypothesis be verified, mineralogic analysis by X-ray diffraction theoretically would permit reconstruction of past maximum water-table elevations.

\section{INTRODUCTION}

Yucca Mountain is being evaluated by the U.S. Department of Energy for suitability as a potential high-level nuclear-waste repository. This report presents a summary of preliminary studies by the U.S. Geological Survey (USGS) of the stable isotopic compositions and formation temperatures of secondary silica mineralization from pedogenic, unsaturated zone (UZ), saturated zone (SZ), and moderate-temperature hydrothermal settings in and near Yucca Mountain in Nye County, southwestern Nevada (fig. 1). Stableisotope analyses of secondary silica and coexisting calcite, recovered from near-surface pedogenic deposits, fracture coatings, lithophysal cavity fillings, and veins, can provide a record of the temperature and sources of ground water within the mountain. In particular, where stable-isotope studies indicate that the silica precipitated in equilibrium with another phase, such as calcite, both the temperature of formation and the isotopic composition of the fluid, hence its hydrologic history, can be uniquely inferred. In addition, these studies may also provide tools for determining past water-table elevations and for reconstructing past hydrology and climate. Herein, the term silica is used informally to refer to that group of minerals and mineraloids containing only $\mathrm{SiO}_{2}$.

\section{ACKNOWLEDGMENTS}

We would like to thank Schön Levy (Los Alamos National Laboratory) for a careful and critical review of this manuscript. Silica stable isotopic analyses were provided by Carol Gent (U.S. Geological Survey, Denver, Colorado). Thanks to E.A. McConnaughey (Science Applications International Corporation, Denver, Colorado) for valuable discussions, and to 


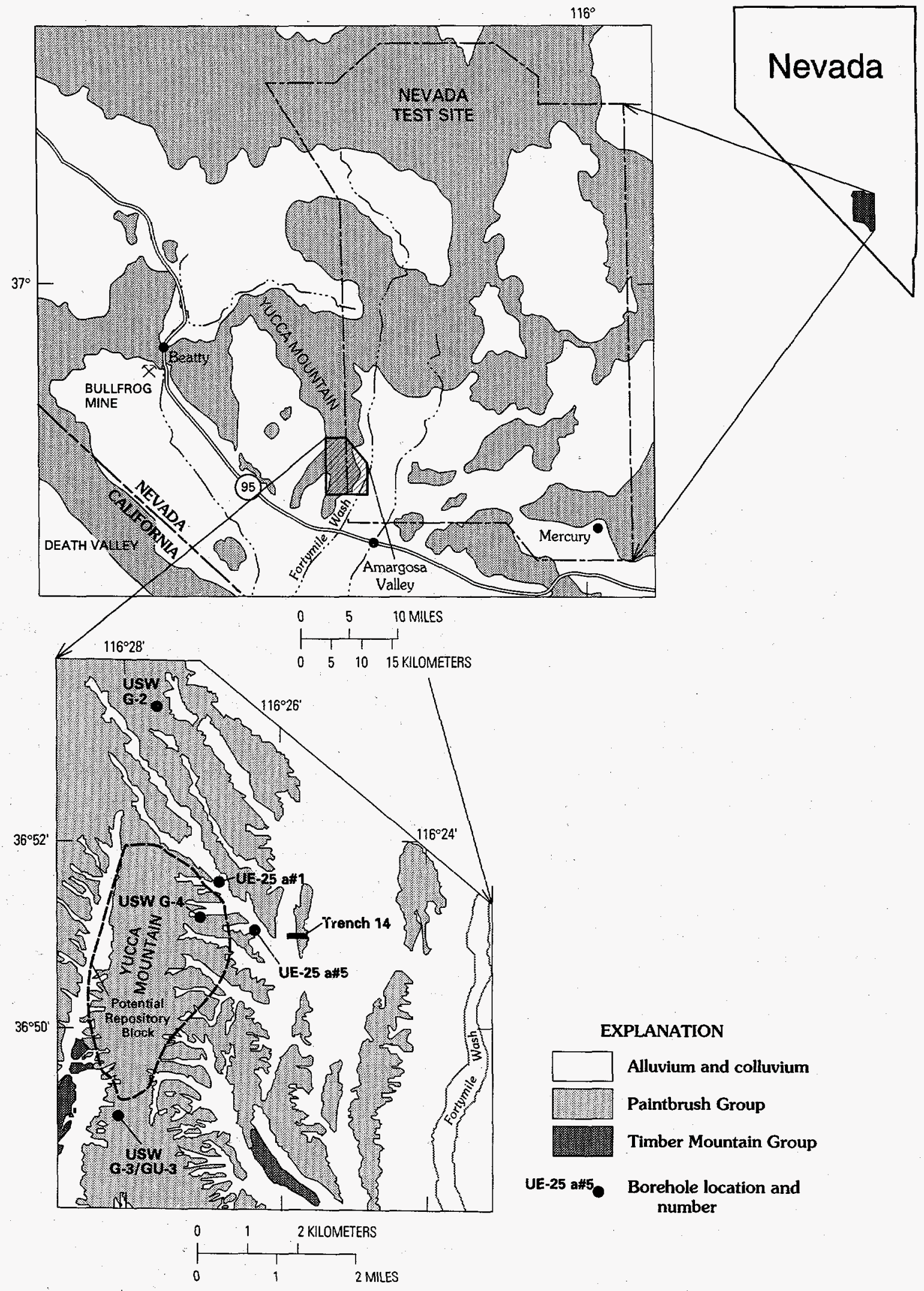

Figure 1. Location of Yucca Mountain region and potential repository site, sampled boreholes, Trench 14, and the Bullfrog Mine. 
David Vaniman (Los Alamos National Laboratory) for providing pure separates of opal from Trench 14 samples.

\section{GEOLOGIC SETTING}

Yucca Mountain is located within the southwestern Nevada volcanic field (Christiansen and others, 1977). The $150 \mathrm{~km}^{2}$ area being studied is located about $120 \mathrm{~km}$ northwest of Las Vegas. This geologic province consists of locally thick and commonly faulted sequences of Miocene- and Pliocene-age silicic lavas and ash-flow tuffs that were erupted 15 to $10 \mathrm{Ma}$ from the Timber Mountain and Silent Canyon calderas (Noble and others, 1968). This faulting, along with fracturing and brecciation during cooling, formed many pathways for potential fluid movement within the volcanic rocks. Furthermore, Yucca Mountain was progressively tilted and faulted to the northeast during the Miocene (Levy, 1991). The dip and fault offsets of the older rock units are commonly greater than those of the younger units, with some of the dip reflecting pyroclastic deposition on already inclined surfaces (Carr, 1984). Paleozoic marine carbonates, and locally, granitic plutons, underlie the volcanic section.

Most of the samples discussed here are from the Paintbrush Group, a sequence of generally devitrified, moderately to densely welded ash-flow tuffs. The individual tuffs of the Paintbrush Group are more densely welded in the middle, reflecting the area of greatest heat retention within the individual tuffs during cooling, where welding occurred by viscous flow of glass particles. Subsidiary syngenetic features, formed during cooling, include lithophysal zones (concentrations of former gas cavities) that are lined with vapor-phase alkali feldspar, cristobalite, and tridymite and may contain later calcite and minor opal and quartz and zones of vapor-phase alteration (Levy, 1992). The mineralogy of the devitrified pyroclastic units is primarily cristobalite, alkali feldspar, tridymite, and quartz with minor amphibole, pyroxene, biotite, iron/titaniumoxides, and alteration phases (Bish and Chipera, 1989). The potential repository site is within the Topopah Spring Tuff of the Paintbrush Group, approximately $350 \mathrm{~m}$ above the current water-table level (Ervin and others, 1994) and $450 \mathrm{~m}$ below the surface of Yucca Mountain (fig. 2).

\section{SILICA AND CALCITE PETROLOGY}

Silica and calcite samples came from three different geologic settings: (1) Pedogenic (Trench 14); (2) secondary mineralization coating fractures and lithophysal cavities within the UZ; and (3) lowtemperature hydrothermal deposits from the saturated zone (SZ) and moderate-temperature hydrothermal deposits from the Bullfrog Mine (near Beatty, Nevada, fig. 1).

The pedogenic calcite from Trench 14 is commonly micritic. It forms displacive intergranular cements, laminated soil horizons and fracture fillings, and coatings on colluvial cobbles and pebbles within the thin soils around Yucca Mountain. Opaline silica, both amorphous (opal-A) and more commonly with short range cristobalite/tridymite ordering (opal-CT) (Vaniman and others, 1992; Jones and Segnit, 1971), is commonly interlaminated or intergrown with the pedogenic calcite and typically occurs as uniform thin lamellae or botryoidal masses. Pedogenic opal precipitation is facilitated by vegetation through plant acids excreted to solubilize soil nutrients, organic acids generated during plant-matter decomposition, and root respiration (E.A. McConnaughey, Science Applications International Corporation, oral commun., 1995). Stuckless and others (1992) suggest that the more abundant opal-CT may reflect dissolution and redeposition of opal-A of biogenic or inorganic origin. Soil detritus and bedrock may also provide silica sources.

Secondary calcite and, to a lesser extent, silica are found as fracture coatings in vapor-phase cavities and in veins of UZ tuffs. All of the silica-calcite sample pairs from boreholes were recovered from formations of the Paintbrush Group (Topopah Spring, Pah Canyon, Yucca Mountain, and Tiva Canyon Tuffs) (fig. 2).

Unsaturated-zone calcite occurs as patchy to nearly complete coatings on fractures. In the upper 10 to $13 \mathrm{~m}$ of the $\mathrm{UZ}$, the calcite is micritic and generally similar to that in the pedogenic setting. In the remainder of the UZ, the calcite is sparry and often forms drusy, 1 to 2-mm-thick, water-clear coatings with en echelon crystal surfaces, translucent fan-shaped blades up to $1 \mathrm{~cm}$ long, irregular masses of 1 to $3 \mathrm{~mm}$, modified scalenohedrons, or veinlets. The UZ calcite fluoresces bright white with bluish tints in short-wave ultraviolet light and typically phosphoresces strongly. Phosphorescence and fluorescence gradually fade proportionally with sample depth and are faint or absent in samples from deep in the UZ.

Although quartz, chalcedony, tridymite, and cristobalite are also found in the UZ, the late opal often associated with calcite is the primary focus of this study. Unsaturated-zone opal, most commonly opal-CT (Szabo and Kyser, 1990), is easily recognized by its clear to translucent, white to bluish gray, botryoidal clusters $1-3 \mathrm{~mm}$ in diameter. In short-wave ultraviolet light, the opal has a very characteristic bright greenish-yellow fluorescence, even when overlain by calcite. 


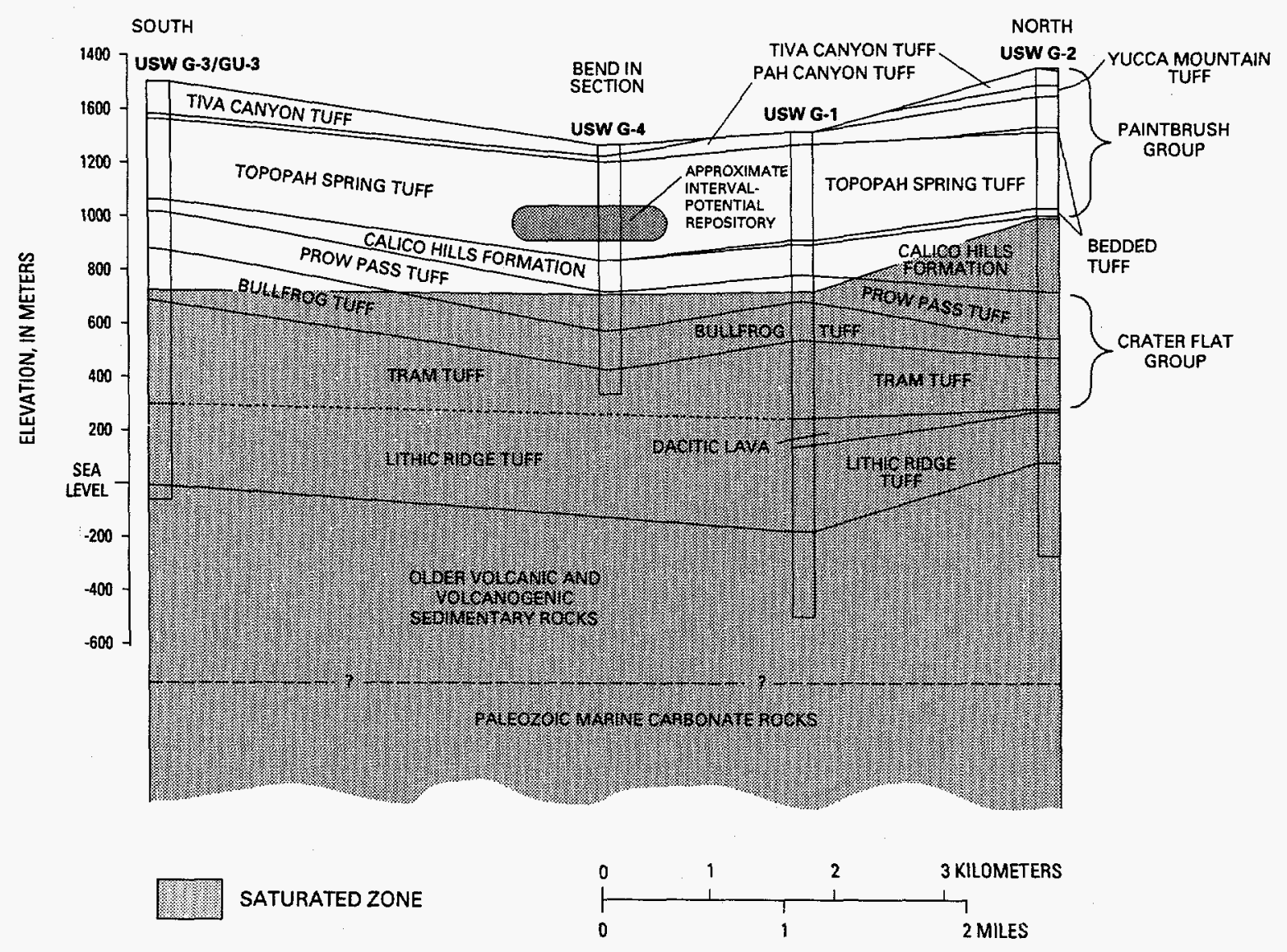

Figure 2. Approximately north-south, generalized cross section of Yucca Mountain showing geology, water table, and boreholes. 
Throughout the UZ, calcite and opal deposition appear to be mutually exclusive, with both phases mantling uncorroded forms of the other, although the opal sometimes appears to have replaced calcite. This is significant in that it represents textural evidence that the calcite and opal record different temperature or fluid geochemical conditions.

Quartz textures in the UZ range from finegrained drusy coatings to massive coatings to large (2-5 mm) water-clear, euhedral, and prismatic crystals or groups of crystals that form sprays or rosettes. Chalcedony is typically light gray with a dense, massive, microcrystalline texture. Tridymite formed from deuteric fluids during tuff cooling as a high-temperature devitrification or vapor-phase crystallization product. It occurs as tabular prismatic crystals and is most noticeable as a drusy lining of lithophysal cavities. $\mathrm{X}$-ray diffraction analyses indicates that both quartz and cristobalite may pseudomorphically replace tridymite (Carlos and others, 1991), but mineralogic compositions of vapor-phase samples were not determined.

Silica in the SZ occurs as euhedral quartz crystals or banded chalcedony that typically line fractures filled with later minerals, including calcite. Saturatedzone calcite is typically an anhedral, milky, veinfilling, or replacement cement that fluoresces bright orange but does not phosphoresce. The two silicacalcite sample pairs from the SZ (from borehole USW G-2) reported here are assumed to be part of the low-temperature hydrothermal alteration assemblage described by Broxton and others (1987).

The Bullfrog gold deposit near Beatty, Nevada, is hosted by Miocene volcanic rocks that are possibly correlative with the Yucca Mountain section. Hydrothermal silica and calcite from the Bullfrog Mine were studied for comparison with the early alteration assemblage found at Yucca Mountain. Silica occurs throughout the Bullfrog Mine deposit as translucent euhedra of quartz, 2-3 mm in length; as pervasive silicification; and as late, thin coatings of botryoidal opal. Except for the pervasive silicification, these forms are texturally analogous to Yucca Mountain occurrences in the UZ and, perhaps, genetically analogous to Yucca Mountain occurrences in the SZ.

\section{ANALYTICAL METHODS}

The extraction of calcite carbon dioxide followed routine procedures developed by McCrea (1950). The extraction of oxygen from silica samples was performed in two ways. Opals containing 5 percent or more water were analyzed at Arizona State University (see table 1) by stepwise-fluorination
(Haimson and Knauth, 1983). This procedure strips away the oxygen of hydration and adsorbed water, permitting analysis of structural oxygen. Oxygen in silica samples with less than 5 percent water was extracted by routine procedures (Clayton and Mayeda, 1963). All silica samples were treated with warm, dilute hydrochloric acid to remove carbonate impurities and were hand-picked to remove tuff impurities.

The isotopic ratios determined at the U.S. Geological Survey Laboratory were analyzed on a Finnigan MAT 252 mass spectrometer by standard techniques. Precision and accuracy were assessed by replicate analyses of unknowns and repeated analyses of the carbonate standard, NBS-19, and the silica standard, NBS-28. Reproducibility for NBS-19 is \pm 0.10 per mil (\%o) for $\delta^{13} \mathrm{C}$ and $\delta^{18} \mathrm{O}$. Delta ${ }^{18} \mathrm{O}$ values for NBS-28 are reproducible to within $\pm 0.25 \%$. The isotopic compositions reported in table 1 are the per mil differences between the sample isotopic composition and that of the International Standards PDB (Pee Dee Belemnite) for $\delta^{13} \mathrm{C}$ and SMOW (Standard Mean Ocean Water) for $\delta^{18} \mathrm{O}$.

\section{DISCUSSION OF ORIGINS OF SILICA}

Stable isotopes clearly distinguish between the hydrogenic systems that deposited secondary calcite near Yucca Mountain. Figure 3 (Whelan and others, 1994) shows the $\delta^{13} \mathrm{C}$ and $\delta^{18} \mathrm{O}$ values of Yucca Mountain pedogenic carbonate, $\mathrm{UZ}$ calcite, $\mathrm{SZ}$ calcite, and Paleozoic marine carbonate. In the UZ, calcite $\delta^{13} \mathrm{C}$ values range from $-9 \%$ to $+4 \%$, with the majority between $-9 \%$ and $-3 \%$. This range is nearly identical to that of the soil carbonate $(-8 \% \circ$ to $-4.5 \%$ o $)$ on and surrounding Yucca Mountain (Whelan and Stuckless, 1990). Whelan and others (1994) concluded that the UZ calcite deposited from meteoric waters that had interacted with soils at the surface carried dissolved carbonate into the mountain along fracture pathways. Szabo and Kyser (1990) suggest that the regular decrease in $\delta^{18} \mathrm{O}$ values with depth is compatible with an increase in temperature of the precipitating fluid as it responds to the local geotherm.

The SZ, in contrast, has calcite whose $\delta^{13} \mathrm{C}$ values (-2\%o to $3 \%$ ) reflect that of the underlying Paleozoic marine limestones (about 1.0\%o) (Whelan and others, 1994). These secondary calcites were likely deposited during alteration by heated ground waters from the underlying Paleozoic limestone aquifer, possibly associated with the formation of the Timber Mountain Caldera, 10.4 Ma (Broxton and others, 1987). 
Table 1. Secondary silica and calcite $\delta^{18}$ O values from pedogenic, unsaturated zone, saturated zone, and Bullfrog Mine samples at and near Yucca Mountain, Nevada

$[*$, indicates the second cut in the stepwise fluorination procedure of Haimson and Knauth (1983). This fraction of the oxygen is that from the silicate structure without labile water and represents most accurately initial opal formation. No value, indicates that either there was no coexisting calcite to calculate a temperature or that $\delta^{18} \mathrm{O}$ of silica was less than $\delta^{18} \mathrm{O}$ of calcite, producing a negative $\delta^{18} \mathrm{O}_{\text {silica-calcite }}$, which prohibits calculation. Abbreviations: Cc, calcite; qtz, quartz; tridy, tridymite; chalced, chalcedony; SMOW, Standard Mean Ocean Water; ASU, Arizona State University; USGS, U.S. Geological Survey; ESF, Experimental Studies Facility; Temp. ${ }^{\circ} \mathrm{C}$, temperature in degrees Celsius]

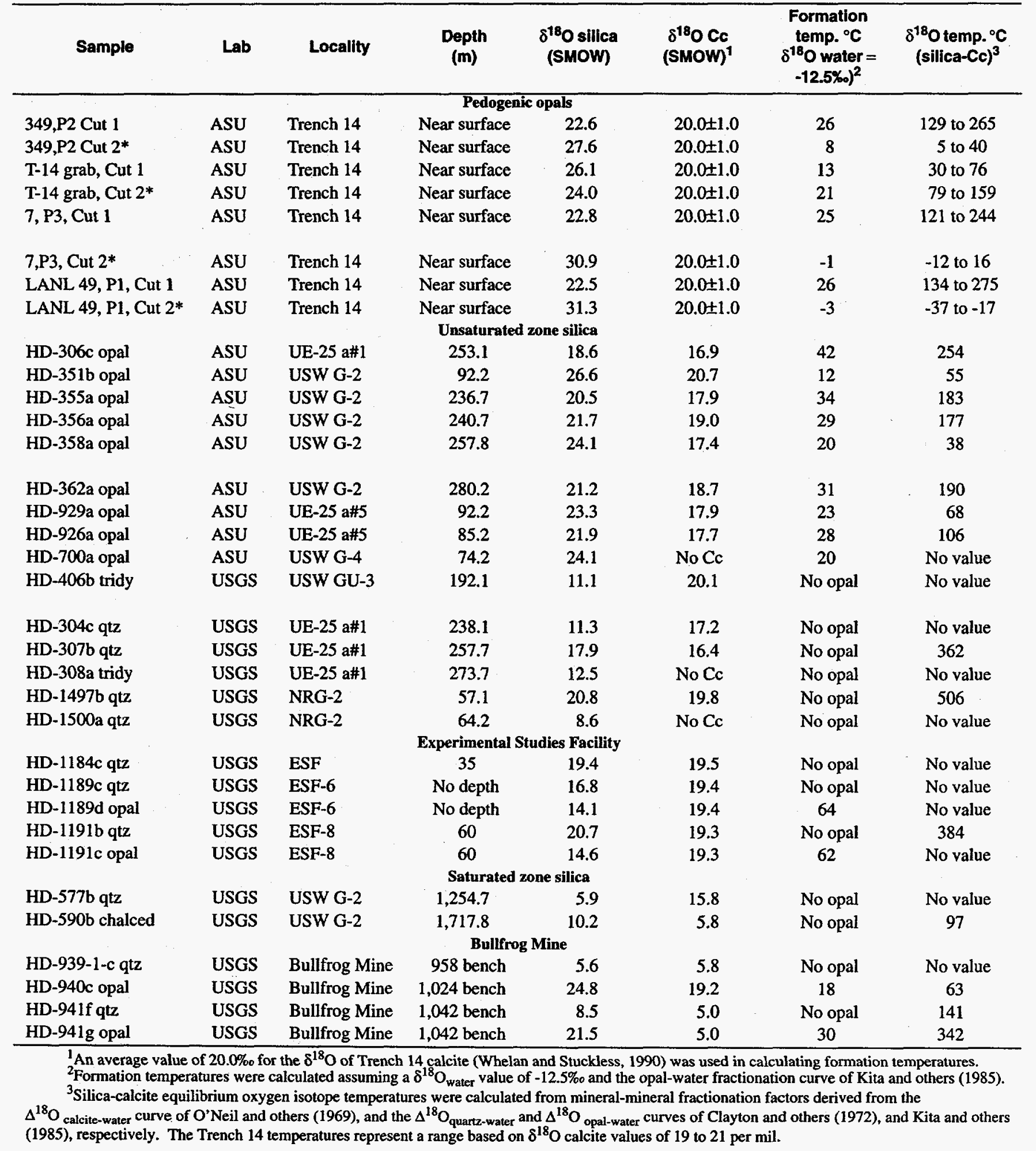

6 Origins of Secondary Silica Within Yucca Mountain, Nye County, Southwestern Nevada 


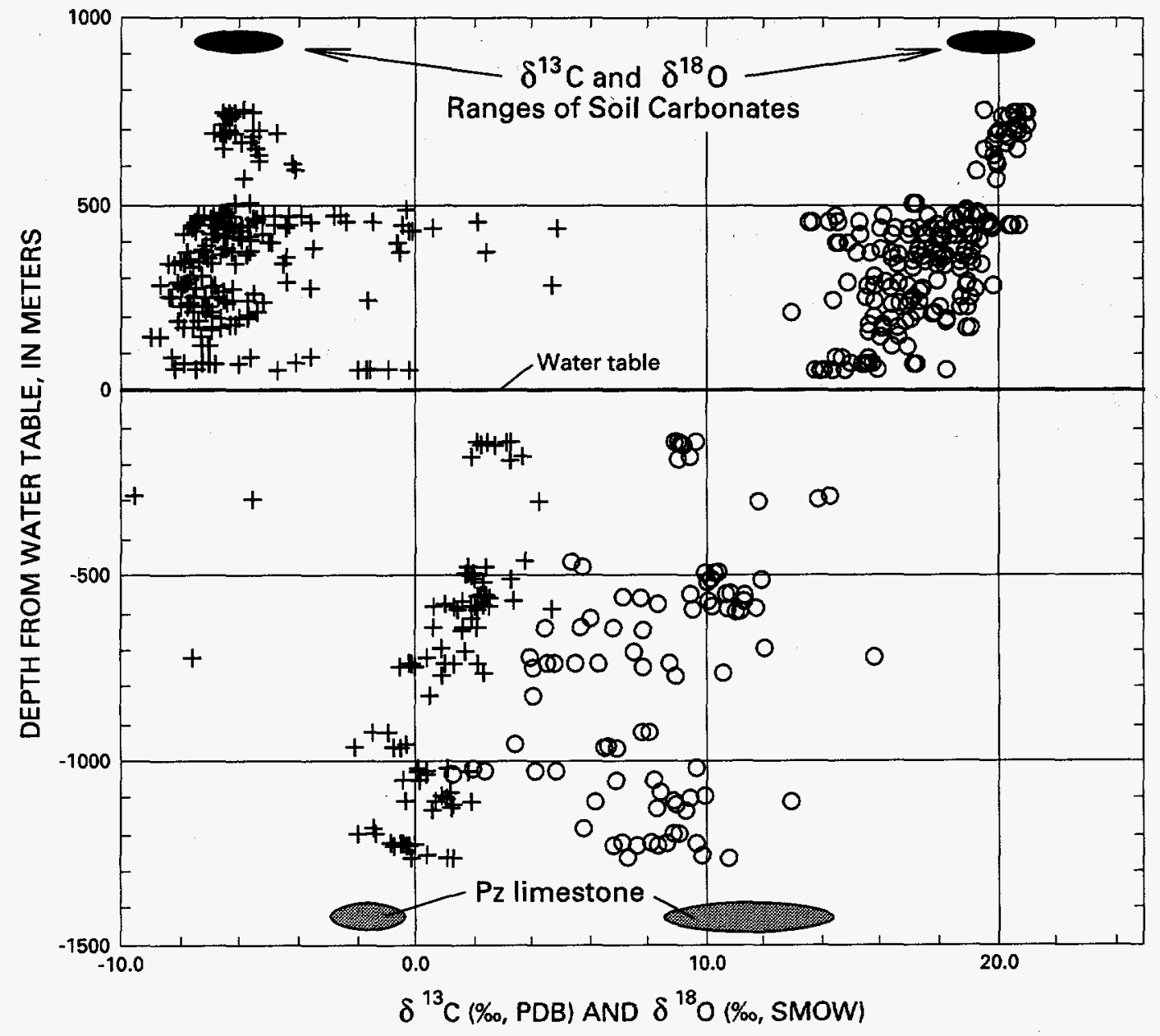

Figure 3. Delta ${ }^{13} \mathrm{C}$ (crosses) and $\delta^{18} \mathrm{O}$ (circles) values of secondary calcite from all boreholes with respect to location of the water table. PDB (Pee Dee Belemnite), SMOW (Standard Mean Ocean Water), $\mathrm{Pz}$ (Paleozoic). 
Isotope fractionation is indicated by the fractionation factor $\alpha$ which is defined as:

$$
\alpha=\mathbf{R}_{\mathbf{A}} / \mathbf{R}_{\mathbf{B}}
$$

where

$R_{A}$ is the ratio of the heavy to the light isotope in phase $\mathrm{A}$; and

$R_{B}$ is the ratio of the heavy to the light isotope in phase $B$.

Formation temperatures in this report are calculated using the following experimentally determined fractionation factors between water and quartz, amorphous silica (opal), or calcite over the temperature range 0 to $300^{\circ} \mathrm{C}$ (fig. 4):

$$
1000 \ln \alpha_{\text {qzA-water }}=3.38\left(10^{6} / \mathrm{T}^{2}\right)-3.40
$$

(Clayton and others, 1972)
$1000 \ln \alpha_{\text {opal-water }}=3.52\left(10^{6} / \mathrm{T}^{2}\right)-4.35$

(Kita and others, 1985)

$$
1000 \ln \alpha_{\text {cc-water }}=2.78\left(10^{6} / \mathrm{T}^{2}\right)-3.39
$$

(O'Neil and others, 1969)

Oxygen isotope fractionation curves for opal in relation to calcite,

$$
1000 \ln \alpha_{\text {opal-cc }}=0.74\left(10^{6} / \mathrm{T}^{2}\right)-0.96
$$

and for quartz in relation to calcite,

$$
1000 \ln \alpha_{\mathrm{qz}-\mathrm{cc}}=0.60\left(10^{6} / \mathrm{T}^{2}\right)-0.01
$$

were derived by difference from the experimental curves. The difference between the $\delta^{18} \mathrm{O}$ values of any two phases $\left(\Delta^{18} \mathrm{O}\right)$, which is closely equivalent to $1000 \ln \alpha$, was used in the temperature calculations.

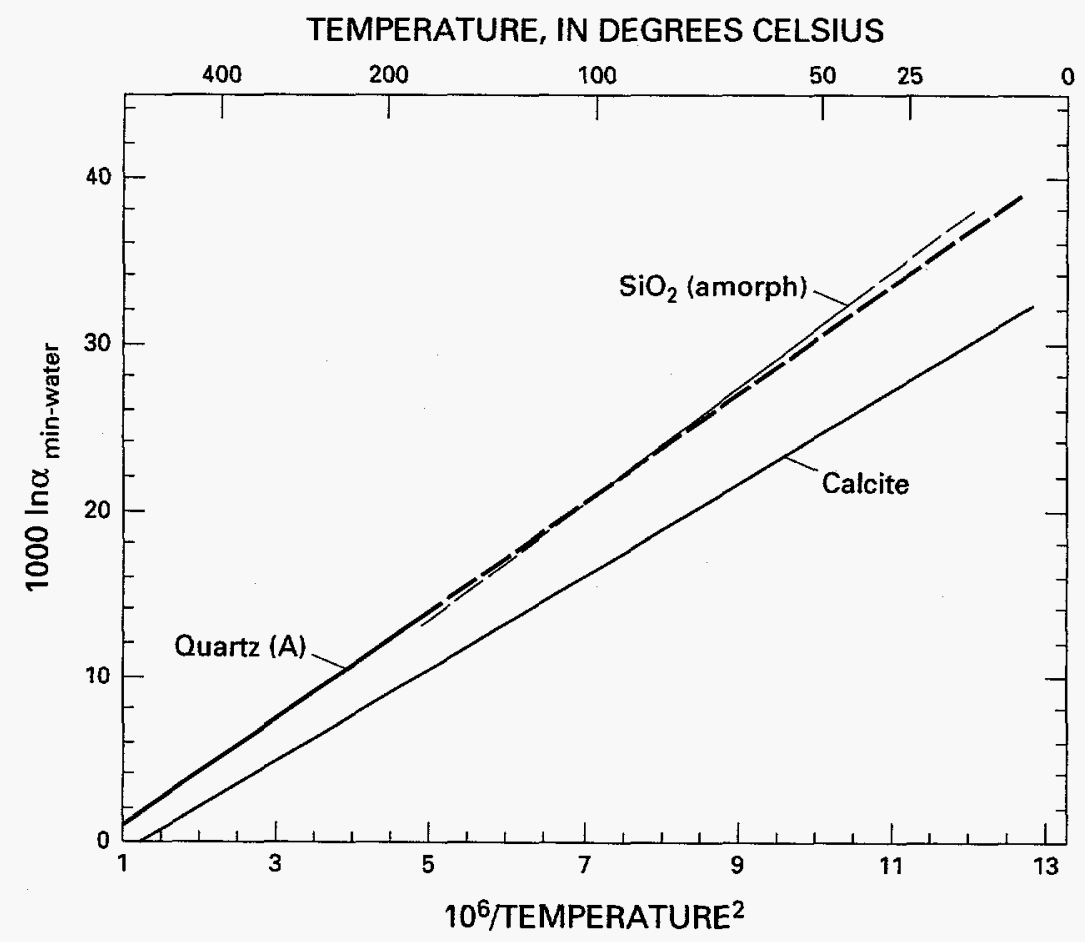

Figure 4. Variation in $1000 \mathrm{In} \alpha$ (mineral-water) with temperature for ${ }^{18} \mathrm{O}$ in silica and calcite. Data from Kita and others (1985), Clayton and others (1972), and O'Neil and others (1969). 


\section{Pedogenic Silica}

Opaline silica sampled from Trench 14 has $\delta^{18} \mathrm{O}$ values that range from $22.6 \%$ o to $31.3 \%$ o (fig. 5 and table 1). This range includes the first step fluorination reaction that removes oxygen bound in labile water. The range narrows to $24.0 \%$ o to $31.3 \%$ when only the second step (silicate-bound oxygen) analyses are used, and it is these values only that are discussed here.

Preliminary analyses of modern precipitation at Yucca Mountain indicate that it has an average $\delta^{18} \mathrm{O}$ value of $-12.5 \% \circ$ (Moscati and Whelan, 1994). Table 1 shows oxygen isotope temperatures calculated from the opal $\delta^{18} \mathrm{O}$ values and a precipitation $\delta^{18} \mathrm{O}$ value of $-12.5 \%$. Using these values, depositional temperatures of the Trench 14 opals range from $-3^{\circ}$ to $21^{\circ} \mathrm{C}$ and average about $6^{\circ} \mathrm{C}$, a temperature somewhat lower than modern surface conditions (Szabo and Kyser, 1990). Assuming a value of $20.0 \pm 1.0 \%$ of $\delta^{18} \mathrm{O}$ of coexisting calcite, a reasonable average for Trench 14 samples (Whelan and Stuckless, 1990), and equilibrium oxygen isotopic fractionation, the opal-calcite pairs indicate formation temperatures ranging from $-37^{\circ}$ to $159^{\circ} \mathrm{C}$. This large scatter of temperatures supports the textural evidence that opal and calcite deposited from fluids of somewhat different chemistry or at different temperatures. The opal $\delta^{18} \mathrm{O}$ values, although wide ranging, seem to reflect near-surface temperatures, as do the calcite $\delta^{18} \mathrm{O}$ values that have a much smaller range. The wide range of opal $\delta^{18} \mathrm{O}$ may indicate the existence of variable fluid $\delta^{18} \mathrm{O}$ values during opal formation, possibly due to ${ }^{18} \mathrm{O}$-enrichment of the soil waters by evaporation. Soil chemical conditions leading to opal and calcite formation and the resulting evidence for the chemistries of fluids percolating into the $\mathrm{UZ}$ are currently under study.

\section{Unsaturated Zone Silica}

Opal $\delta^{18} \mathrm{O}$ values in the UZ range from $18.6 \%$ o to $26.6 \%$. Figure 6 illustrates the calculated temperatures of the soil zone and UZ opals as a function of depth. Assuming an initial $\delta^{18} \mathrm{O}$ of water of $-12.5 \%$, the calculated temperatures for $\mathrm{UZ}$ opal formation range from $12^{\circ}$ to $42^{\circ} \mathrm{C}$ and may indicate an increase in fluid or temperature $\delta^{18} \mathrm{O}$ with depth. More ${ }^{18} \mathrm{O}$-depleted fluids, that may have infiltrated during past wetter cli- mates, may indicate cooler temperatures of opal formation (Whelan and others, 1994).

Szabo and Kyser (1990) assumed a geothermal gradient of $34^{\circ} \mathrm{C} / \mathrm{km}$ that seemed to coincide well with their calcite $\delta^{18} \mathrm{O}$ data. The trend of opal $\delta^{18} \mathrm{O}$ with depth suggests a somewhat higher geothermal gradient. This may reflect ${ }^{18} \mathrm{O}$ enrichment of opal-depositing fluids, through evaporation in the soil zone or during percolation through the $\mathrm{UZ}$, and is another indication of a fundamental difference between opal- and calcitedepositing fluids or in the processes by which opal and calcite are deposited from fluids.

Opal-calcite oxygen-isotope fractionation temperatures calculated from the opal- $\mathrm{H}_{2} \mathrm{O}$ and calcite$\mathrm{H}_{2} \mathrm{O}$ curves of Kita and others (1985) and Clayton and others (1972), respectively, ranged from $38^{\circ}$ to $254^{\circ} \mathrm{C}$. This scatter of temperatures is further evidence that the calcite and opal deposited from different fluids.

Three samples from Tiva Canyon Tuff exposures in the box cut for the Exploratory Studies Facility (ESF) north ramp starter tunnel consisted of opal and quartz with subsidiary calcite on large open fractures and within breached lithophysal cavities. They are somewhat unusual in being dominated by opal and quartz and because the opal is paragenetically older than the quartz. Textural studies (S. Levy, Los Alamos National Laboratory, oral commun., 1995) indicate that some of the quartz may have formed during the dissolution of earlier opal. Interestingly, the opal had lower $\delta^{18} \mathrm{O}$ values (14.1\%o and $14.6 \%$ o) than the quartz (16.8\%o to $20.7 \%$ ). Thus, although the paragenesis of quartz following opal is reversed from that typical of UZ drill-core occurrences, the isotopic "paragenesis" of early silica having lower $\delta^{18} \mathrm{O}$ values than later silica is maintained. The fact that the calcite-opal $\delta^{18} \mathrm{O}$ differences from the ESF suggest reasonable formation temperatures $\left(62^{\circ}\right.$ and $\left.64^{\circ} \mathrm{C}\right)$ must be coincidental; the calcite is later than the quartz and apparently much younger than the opal.

Secondary quartz in the UZ is limited in distribution and, when observed, it is older than the associated calcite. The depositional setting and timing are constrained only by the early metasomatism of the tuffs and the onset of secondary calcite-opal formation. This may have occurred during short-lived hydrothermal events while the tuffs cooled or from cooler fluids any time since. Quartz $\delta^{18} \mathrm{O}$ values in the $\mathrm{UZ}$ range from $8.6 \%$ to $20.8 \%$, a wide range that may reflect possible conditions under which this quartz may have formed. Attempts to determine depositional temperatures from borehole quartz-calcite sample pairs in the UZ were 


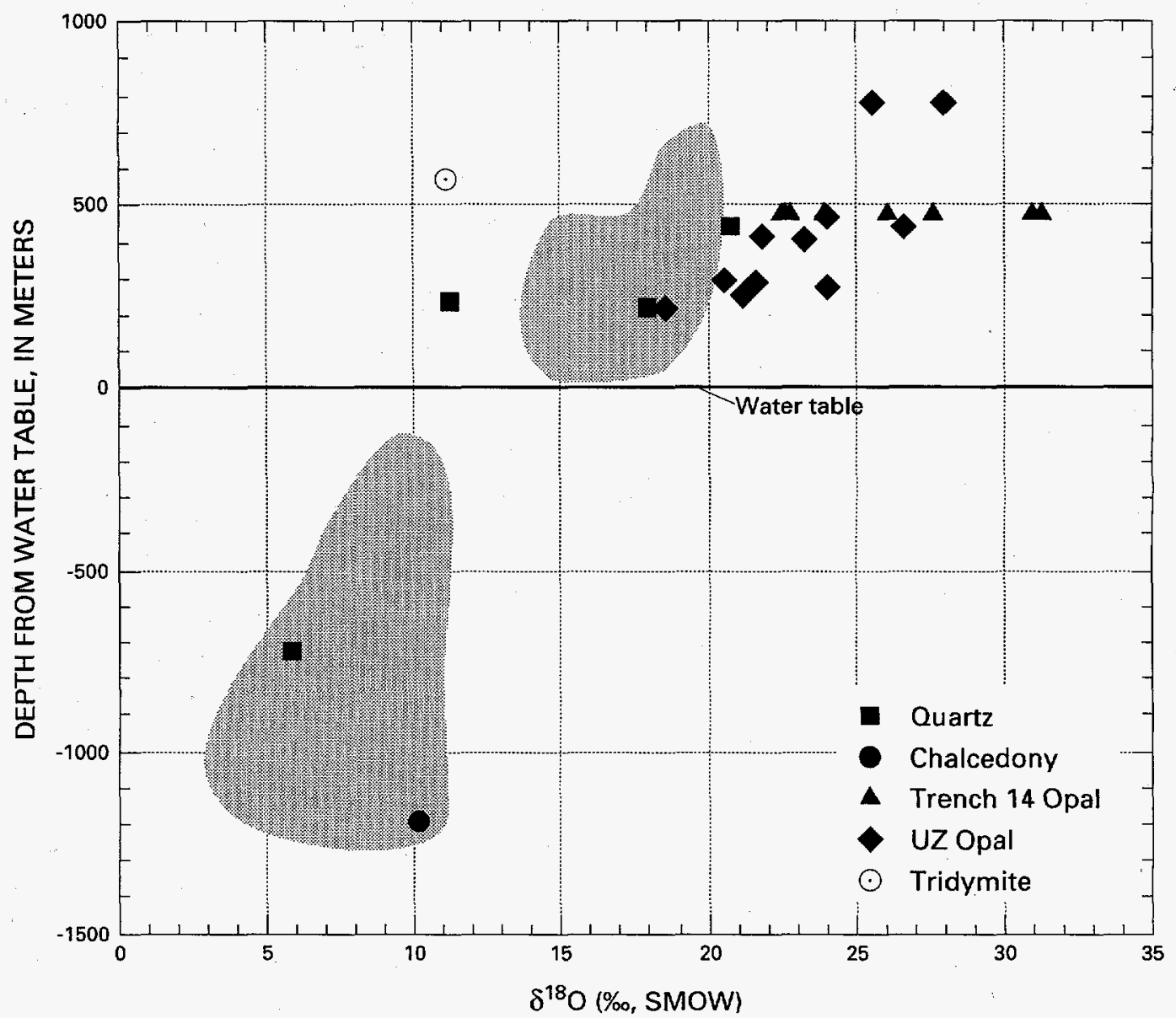

Figure 5. Delta ${ }^{18} \mathrm{O}$ values of pedogenic and borehole secondary silica samples. Shaded fields are ranges of calcite $\delta^{18} \mathrm{O}$ from figure 3. SMOW (Standard Mean Ocean Water), UZ (Unsaturated Zone). 


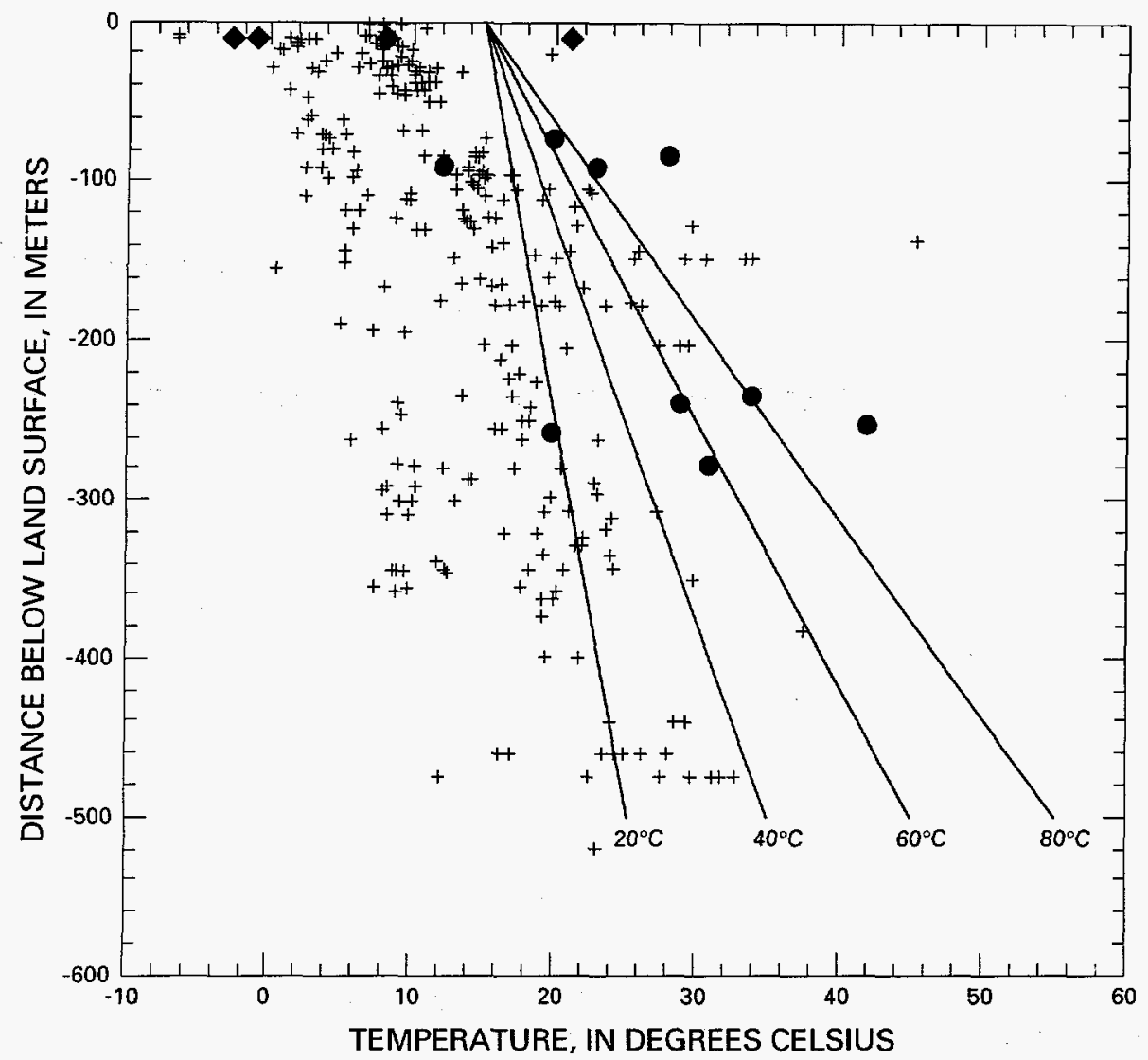

Figure 6. Calculated temperatures, assuming $\delta^{18} \mathrm{O}$ water $=-12.5 \%$ (Moscati and Whelan, 1994), of Trench 14 soil zone opals (diamonds), unsaturated zone opals (circles), and unsaturated zone calcite (crosses). Solid lines represent geothermal gradients in ${ }^{\circ} \mathrm{C} / \mathrm{km}$ based on an estimated mean annual ground-surface temperature of $14.8^{\circ} \mathrm{C}$ (Sass and others, 1980).

futile (table 1). The fact that the quartz sometimes has lower $\delta^{18} \mathrm{O}$ values than calcite from the same sample (that is, isotopic disequilibrium; see fig. 4), verifies that the quartz represents a different depositional environment.

A low-temperature origin for the UZ secondary opal and calcite is further corroborated petrographically by the absence of high temperature or hydrothermal mineralization in the upper sections of the examined drill cores (Carlos and others, 1991) and by the common occurrence of opal-CT as the silica polymorph (Vaniman and others, 1992), which is characteristic of low temperatures. Furthermore, fluid-inclusion studies of UZ calcite indicate formation at temperatures no greater than $100^{\circ} \mathrm{C}$ and in the presence of atmospheric gases (Roedder, 1994).

Two samples of vapor-phase tridymite from lithophysal cavities have $\delta^{18} \mathrm{O}$ values of $11.1 \%$ and
12.5\%. These isotopic compositions are in accord with tridymite formation from deuteric fluids released by the crystallizing tuffs during early cooling (B.D. Marshall, U.S. Geological Survey, written commun., 1995).

\section{"Hydrothermal" Quartz}

The relatively low temperature silica deposits from Trench 14 and the UZ produced, on average, significantly higher $\delta^{18} \mathrm{O}$ values than the "hydrothermal" alteration quartz, $5.9 \%$, and chalcedony, $10.2 \%$, from the SZ and the two hydrothermal quartz samples from the Bullfrog Mine, 5.6\%o and 8.5\%o, near Beatty, Nevada, (fig. 7).

Fluid-inclusion studies of SZ calcite were carried out on similar drill-core samples from Yucca Mountain 


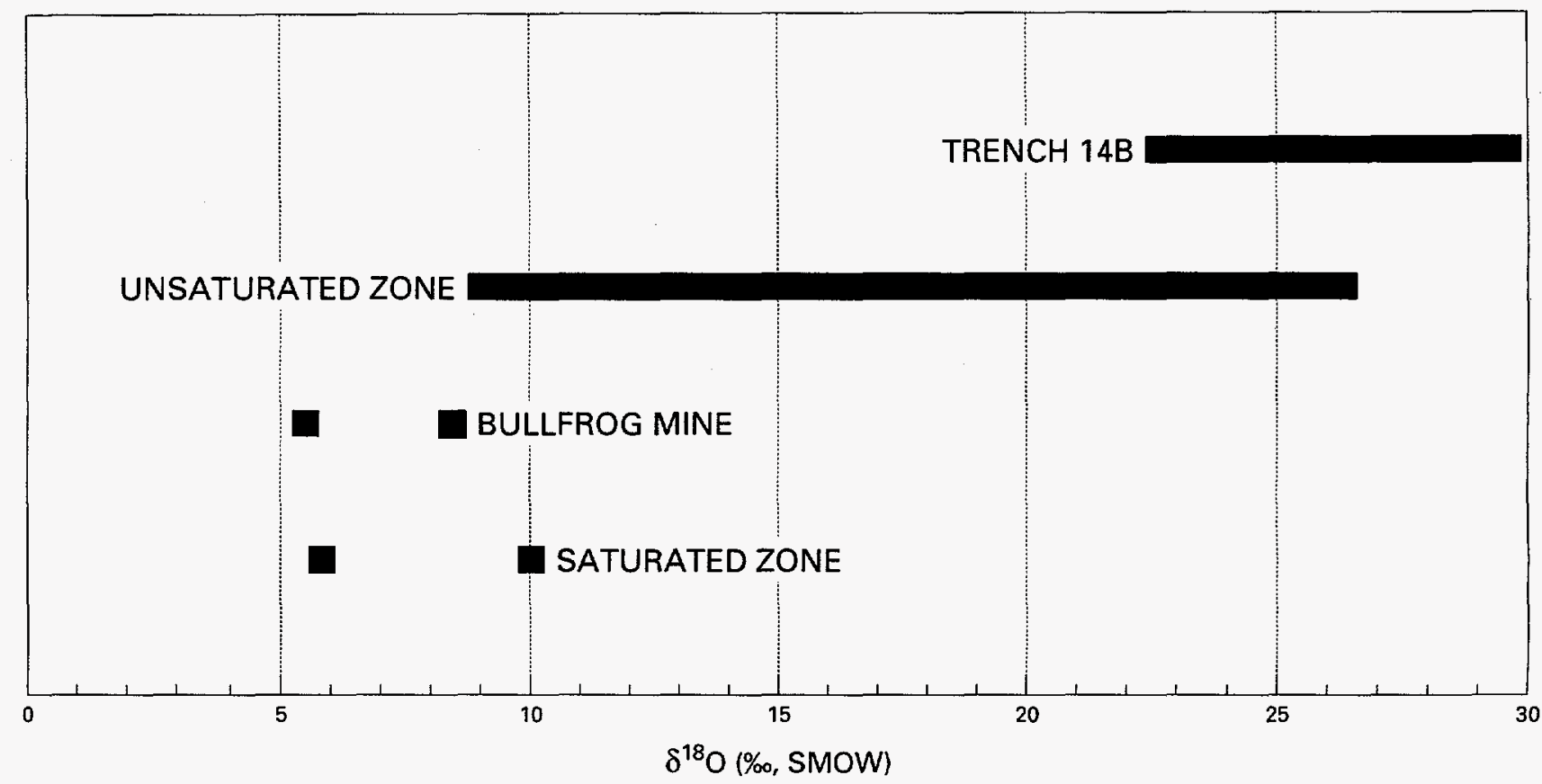

Figure 7. Delta ${ }^{18} \mathrm{O}$ values of the relatively lighter Bullfrog Mine and saturated zone silica samples relative to those in Trench 14 and the unsaturated zone. SMOW (Standard Mean Ocean Water).

by Roedder and others (1994). Their work indicated the SZ calcite formed from fluids with temperatures reaching $250^{\circ} \mathrm{C}$. These temperatures likely reflect the 10.4 Ma hydrothermal event that has been documented in this area by Potassium/Argon age-dating of illite/ smectite pairs from boreholes USW G-1 and USW G-2 (Bish and Aronson, 1993). Assuming alteration temperatures of $150^{\circ}-250^{\circ} \mathrm{C}$ (consistent with Bish and Aronson's illite/smectite geothermometry), these silica samples were in equilibrium with altering fluids having $\delta^{18} \mathrm{O}$ values in the range $-10 \%$ o to $+1 \%$. Deep SZ calcite, whose $\delta^{18} \mathrm{O}$ generally ranges from approximately $4 \%$ to $10 \%$, would have been in equilibrium with altering fluids in the range $-8 \%$ to $+3 \%$, in reasonable agreement with the range predicted from quartz $\delta^{18} \mathrm{O}$ values. The larger $\delta^{18} \mathrm{O}$ values in these ranges probably would indicate some degree of ${ }^{18} \mathrm{O}$ enrichment due to water/rock interaction.

\section{CONCLUSIONS}

Pedogenic and UZ silica samples at Yucca Mountain were likely deposited from the downward percolation of meteoric water. Preliminary evidence suggests a complex history of episodic, but very repetitive, fluid flow through the fractured pyroclastic flows and air-fall deposits. Soil-zone opal and calcite $\delta^{18} \mathrm{O}$ indicate different soil geochemistries with greater evaporative effects suggested by opal $\delta^{18} \mathrm{O}$ values. The isotope data imply that the silica and calcite were deposited independently of one another in response to different climate states that may have affected vegetation, fluid salinity, and/or $\mathrm{pH}$ variations in the soil. The effect of past climate and vegetation changes on soil geochemistry and on infiltrating fluids is important to unraveling the hydrologic response to paleoclimatic variations recorded by secondary mineralization in the UZ.

The SZ and Bullfrog Mine silica samples were deposited in the tuffs in response to hydrothermal convection system(s) about 10.4 Ma. The fluids were probably Paleozoic aquifer waters that had acquired their geochemical signature through thermally-driven interaction with the marine carbonate host rocks. At SZ depths, alteration fluid temperatures in this system are estimated to have reached at least $250^{\circ} \mathrm{C}$. 
This is a preliminary report based on a small sampling population. Additional data would permit better definition of the Miocene "hydrothermal" geotherm and verification of the apparent rarity of silica and calcite coprecipitation, and complement the current Uranium/Thorium geochronology of the UZ fracture flow in the past and the effect of past climate states on the chemistry of the UZ.

\section{SELECTED REFERENCES}

Bish, D.L., and Aronson, J.L., 1993, Paleogeothermal and paleohydrologic conditions in silicic tuff from Yucca Mountain, Nevada: Clays and Clay Minerals, v. 41, no. 2, p. 148-161.

Bish, D.L., and Chipera, S.J., 1989, Revised mineralogic summary of Yucca Mountain, Nevada: Los Alamos National Laboratory Report, LA-11497-MS, 68 p.

Bish, D.L., Ogard, A.E., and Vaniman, D.T., 1984, Mineralogy-petrology and groundwater geochemistry of Yucca Mountain tuffs: Scientific Basis for Nuclear Waste Management, v. VII, p. 283.

Broxton, D.E., Bish, D.L., and Warren, R.G., 1987, Distribution and chemistry of diagenetic minerals at Yucca Mountain, Nye County, Nevada: Clays and Clay Minerals, v. 35, no. 2, p. 89-110.

Carlos, B.A., Bish, D.L., and Chipera, S.J., 1991, Fracturelining minerals in the lower Topopah Spring Tuff at Yucca Mountain in High Level Radioactive Waste Management, Proceedings of the 2d International Conference: La Grange Park, Ill., America Nuclear Society, p. 486-493.

Carr, W.J., 1984, Regional structural setting of Yucca Mountain, southwestern Nevada, and Late Cenozoic rates of tectonic activity in part of the southwestern Great Basin, Nevada and California: U.S. Geological Survey Open-File Report, 84-854, 109 p.

Christiansen, R.L., Lipman, P.W., Carr, W.J., Byers, Jr., F.M., Orkild, P.P., and Sargent, K.A., 1977, Timber Mountain-Oasis Valley caldera complex of southern Nevada: Geological Society of America Bulletin, v. 88, p. 943-959.

Clayton, R.N., and Mayeda, T.K., 1963, The use of bromine pentafluoride in the extraction of oxygen from oxides and silicates for isotopic analysis: Geochimica et Cosmochimica Acta, v. 27, no. 1, p. 43-52.

Clayton, R.N., O'Neil, J.R., and Mayeda, T.K., 1972, Oxygen isotope exchange between quartz and water: Journal of Geophysical Research, v. 77, p. 3057-3067.

Ervin, E.M., Luckey, R.R., and Burkhardt, D.J., 1994, Revised potentiometric-surface map, Yucca Mountain and vicinity, Nevada: U.S. Geological Survey WaterResources Investigations Report 93-4000, 25 p.
Haimson, M., and Knauth, L.P., 1983, Stepwise fluorination-A useful approach for the isotopic analysis of hydrous minerals: Geochimica et Cosmochimica Acta, v. 47 , no. 9, p. 1589-1595.

Jones, J.B., and Segnit, E.R., 1971, The nature of opal 1. Nomenclature and constituent phases: Journal of the Geological Society of Australia, v. 18, p. 57-68.

Kita, I., Taguchi, S., and Matsubaya, O., 1985, Oxygen isotope fractionation between amorphous silica and water at $34-93^{\circ} \mathrm{C}$ : Nature, v. 314 , no. 6006 , p. 83-84.

Levy, S.S., 1991, Mineralogic alteration history and paleohydrology at Yucca Mountain, Nevada in High Level Radioactive Waste Management, Proceedings of the $2 d$ International Conference: La Grange Park, IIl., American Nuclear Society, p. 477-485.

Levy, S.S., 1992, Surface-discharging hydrothermal systems at Yucca Mountain-Examining the evidence in Materials Research Society Symposium Proceedings: Boston, Scientific Basis for Nuclear Waste Management, v. XVI, Interrante, C.G., and Pabalan, R.T., eds., v. 294, p. 543-548.

McCrea, J.M., 1950, The isotopic chemistry of carbonates and a paleotemperature scale: Journal of Chemical Physics, v. 18, p. 849-857.

Moscati, R.J., and Whelan, J.F., 1994, Stable isotope compositions and formation temperatures of secondary silica mineralization from pedogenic, drill core, and hydrothermal samples near Yucca Mountain, Nevada: Geological Society of America Abstracts with Programs, v. 26, p. A279.

Noble, D.C., Sargent, K.A., Mehnert, H.H., Ekren, E.B., and Byers, Jr., F.M., 1968, Silent Canyon volcanic center, Nye County, Nevada: in Nevada Test Site, Eckel, E.B., ed., Geological Society of America Memoir 110, p. $65-75$.

O'Neil, J.R., Clayton, R.N., and Mayeda, T.K., 1969, Oxygen isotope fractionation in divalent metal carbonates: Journal of Chemical Physics, v. 51, no. 12, p. 5547-5558.

Roedder, E., Whelan, J.F., and Vaniman, D.T., 1994, Fluid inclusion studies of calcite veins from Yucca Mountain, Nevada, tuffs-Environment of formation in High Level Radioactive Waste Management, Proceedings of the 5th International Conference: La Grange Park, Ill., American Nuclear Society, p. 1854-1860.

Sass, J.H., Lachenbruch, A.H., and Mase, C.W., 1980, Analysis of thermal data from drill holes UE-25a-3 and UE-25a-1, Calico Hills and Yucca Mountain, Nevada Test Site: U.S. Geological Survey Open-File Report $80-826,25$ p. 
Stuckless, J.S., Peterman, Z.E., Forester, R.M., Whelan, J.F., Vaniman, D.T., Marshall, B.D., and Taylor, E.M., 1992, Characterization of fault-filling deposits in the vicinity of Yucca Mountain, Nevada: in Waste Management Proceedings, Tucson, Ariz., p. 929-935.

Szabo, B.J., and Kyser, T.K., 1990, Ages and stable-isotope compositions of secondary calcite and opal in drill cores from Tertiary volcanic rocks of the Yucca Mountain area, Nevada: Geological Society of America Bulletin, v. 102, no. 12, p. 1714-1719.

Vaniman, D.T., Ebinger, M.H., Bish, D.L., and Chipera, S.J., 1992, Precipitation of calcite, dolomite, sepiolite and silica from evaporated carbonate and tuffaceous waters of southern Nevada, USA: in Seventh International
Symposium on Water-Rock Interaction, Park City, Utah, p. 687-691.

Whelan, J.F., and Stuckless, J.S., 1990, Reconnaissance $\delta^{13} \mathrm{C}$ and $\delta^{18} \mathrm{O}$ data from Trench 14 , Busted Butte, and drill hole G-4, Yucca Mountain, Nevada Test Site in High Level Radioactive Waste Management, Proceedings of the 1st International Conference: La Grange Park, Ill., American Nuclear Society, p. 930-933.

Whelan, J.F., Vaniman, D.T., Stuckless, J.S., and Moscati, R.J., 1994, Paleoclimatic and paleohydrologic records from secondary calcite-Yucca Mountain, Nevada in High Level Radioactive Waste Management, Proceedings of the 5th International Conference: La Grange Park, I1l., American Nuclear Society, p. 2738-2745. 